\title{
VESTUÁRIO DE MODA SUSTENTÁVEL
}

\author{
MAICON DOUGLAS LIVRAMENTO NISHIMURA, M.SC. | UFSC \\ LEILA AMARAL GONTIJO, Dra. | UFSC
}

\section{RESUMO}

Na relação de atender os desejos do consumidor, obter sucesso do produto e alcançar a lucratividade, o designer ainda tem de adaptar-se às exigências de mercado para uma orientação sustentável. Assim, com esta pesquisa, objetiva-se identificar elementos que agregam valor ao produto de vestuário de moda sustentável, sob a perspectiva do designer, a fim de propor ao profissional referências de elementos para o desenvolvimento de produto.

A partir desse objetivo, foi desenvolvida uma pesquisa exploratória-descritiva estabelecida em três fases: (1) pesquisa bibliográfica, (2) levantamento de dados, por meio de entrevista semiestruturada, e (3) análise comparativa.

A pesquisa possui caráter quali-quantitativo, sendo que, na etapa quantitativa foram realizadas as categorizações provenientes da aplicação do método de análise de conteúdo e de cálculo de coeficiente de correlação e, na etapa qualitativa, as análises das narrativas dos entrevistados.

Com base nos dados, observa-se, entre os designers entrevistados, predominância do sexo feminino, com idade entre 21 e 40 anos, empreendedores individuais ou societários, que tem como motivação para a sustentabilidade questões de âmbito pessoal ou profissional. Percebe-se, também, que os designers compreendem a sustentabilidade nas dimensões ambiental, social e econômica, sendo que alguns trazem ainda a dimensão cultural para sua definição. Quanto à aplicação dos conceitos de sustentabilidade, houve enfoque para o ciclo de vida do produto, além das dimensões ambiental e cultural. Já o princípio de maior destaque que norteia os designers no desenvolvimento do produto é o slow fashion. As cadeias de suprimentos seguem uma estrutura tradicional, com ajustes devido às restrições de matéria-prima, além de que a terceirização é uma realidade em algumas etapas de produção. O produto de vestuário de moda sustentável possui bom desempenho financeiro, boa aceitação do consumidor e os elementos de valor com maior aparição foram a eficiência, estima, ética, estética e espiritualidade. Entre os diferenciais do produto, a estética é a mais apontada. Ressalta-se ainda que a região pesquisada é favorável para a atuação de negócios sustentáveis devido ao estímulo da economia criativa e de movimentos sustentáveis na moda.

Com isso, foi possível concluir que há engajamento no discurso dos designers, todavia, os desafios no setor da moda demandam mudanças efetivas orientadas ao comportamento de consumo para alcançar um desenvolvimento mais sustentável. 
